\title{
Why Do Agricultural Producers Exhibit at Bread Basket?
}

\author{
M. Havlíková, A. Kolářová \\ Department of Economics, Faculty of Economics and Management, Czech University of Life Sciences \\ Prague, Czech Republic
}

\begin{abstract}
Anotace
Studium odborné literatury prokázalo, že prezentace na veletrhu, je významným marketingovým nástrojem, který umožňuje vystavovatelům představit a testovat nové výrobky, monitorovat konkurenty a rozvíjet vztahy se zákazníky. Tento článek rozšiřuje dosavadní poznatky o faktorech, které motivují vystavovatele k účasti na veletrhu. Výzkum je prováděn na mezinárodním veletrhu Země živitelka. Vystavovatelé v oblasti živočišné a rostlinné produkce i zemědělských technologií hodnotili set motivů pomocí Likertovy škály. Následně provedená faktorová analýza odhalila čtyři klíčové faktory účasti na veletrhu, konkrétně získávání informací a rozvoj společnosti, rozvoj výrobku, zaměření se okolí společnosti a možnosti nových trhů. Logistická regrese poté odhalila, jak vybrané proměnné (klasifikace NACE, rok založení podniku, či četnost účasti na veletrhu) ovlivňují stanovené faktory motivů vystavovatelů k účasti na veletrhu.
\end{abstract}

\section{Klíčová slova}

Veletrh, vystavovatel, motiv, Země živitelka.

\begin{abstract}
A literature survey proved that trade shows are important marketing tools, enabling sellers to present and test new products, to monitor their competitors, and to establish personal contacts with customers. The paper extends the current research of trade shows by analyzing exhibitors' motives for exhibiting. The research is conducted for a traditional international agricultural fair - Bread Basket. Exhibitors, including animal production exhibitors, crop production exhibitors and agriculture technology exhibitors, were offered a list of potential motives for exhibiting and were asked to indicate their agreement (disagreement) on a 5-point Likert scale. Subsequently, a factor analysis revealed four key factors for exhibiting, including searching for information and company development, product development, focus on company surroundings and new market possibilities. Finally, exhibitors were surveyed again in order to choose one of these factors to be the most important one for exhibiting. Logistic regression revealed how the specific variables (NACE classification, year of establishment and frequency of exhibiting) influence the selected factors.
\end{abstract}

\section{Keywords:}

Milk, market power, oligopoly, SFA, European Union.

Havlíková, M. and Kolářová, A. (2015) “Why Do Agricultural Producers Exhibit at Bread Basket?”, $A G R I S$ on-line Papers in Economics and Informatics, Vol. 7, No. 4, pp. 49 - 56, ISSN 1804-1930.

\section{Introduction}

Trade shows, trade fairs and exhibitions are special types of events in which sellers meet their customers. Sanders (2013) defines a trade show as an event where companies in a specific industry gather to showcase and demonstrate their new products and services. A trade fair, on the other hand, is more business-to-client or customer type event. Exhibitions focus primarily to showcase products and services. Sanders also pointed out that language differences play a part in terms of this definition because the term "trade show" is more popular in the USA, whereas "trade fair" is traditionally more frequently used in the $\mathrm{UK}^{1}$. Kellezi (2013) points out that even the academics consider a trade show in different ways including exhibitions, fairs, or trade fairs, all of them agree

\footnotetext{
1 For the purpose of the conducted research, the terms "trade show" and "trade fair" are considered to be mutually replaceable.
} 
that a trade show is a regularly scheduled event, where companies meet their customers and other important parts of an industry.

Kirchgeorg et al. (2010) defines a trade show as an event that is held on specific days and where a large number of companies present their specific products and sell them to customers. Godar and $\mathrm{O}^{\prime}$ Connor (2001) perceive trade shows as a venue at which it is possible to discern a mutual interest between buyers and sellers and to start future cooperation. Trade shows are usually limited in time and provide direct customer contacts. A customer has an opportunity to see the real product and can try it out on the spot. Trade shows help to build and strengthen the company's image and brand, and therefore they are a perfect venue for innovations and news (Přikrylová and Jahodová, 2010). Bonoma (1983) extended this idea and proved that trade shows improve the company image with competitors, customers and the industry in general. Smith (1998) points out that one of the motives for taking part in a trade show is a desire to build up corporate image and reputation.

Trade shows enable firms not only to present their products and receive orders, but also to receive important reactions and feedbacks concerning their product, its distribution and how it is presented (Frain, 1999). Trade shows and fairs are characterized by their multi-functionality. This means that they can perform many functions at once (sales and related customer satisfaction, new information and trends in the field, getting information about the competition or training) and they are also able to help the company to achieve other desirable goals. This is confirmed also by Vysekalová (2014), who mentions that trade fairs represent a multi-functional aspect because they can connect representation of a company with implementation of a production program and establish personal contacts with customers. Trade shows take an advantage of concentration of target customers, building up personal contacts with potential customers, concentration of useful information and adequate surroundings for communication and dealing. Hansen (1996) shows that boosting and keeping up the morale of company employees and of customers are moderately important activities for exhibitors. Barczyk et al. (1989) indicates another motive for exhibiting at trade shows, namely the sales force morale. Shoham (1992) also proves that trade shows can be used to train and motivate the sales force.

Sharland and Balgoh (1996) see trade shows as an effective communication tool and mention that trade shows, from the visitors' point of view, provide an opportunity to get useful information at low cost. Kerin and Cron (1987) and Lilien (1983) point out the importance of relations with customers and the advantage of having personal contacts with customers. Also Yuksel and Voola (2010) find out that the key motivation for participating in travel trade shows is to improve relationships with customers.

Hansen (2004) stresses the need of research dealing with the value of trade shows and buyer -seller relations. The research conducted by AUMA (2011) among German companies found out that $85 \%$ of researched companies find trade fairs and exhibitions important. The highest importance was given only to the company's own homepage. They find personal sales, direct mailing, trade journals, Internet sales, events and public relations as less important. Also Cop and Cara (2014) find out in their study that $97 \%$ respondents considered trade fairs as the most important marketing tool.

Czech entrepreneurs exhibit at trade shows and trade fairs as well. According to an analysis made by SOVA ČR, the trade show and exhibition market was successful in 2014. In 2014, there were organized 276 trade shows and exhibitions by 39 organizations. These tradeshows and exhibitions were visited by 3.19 million visitors. In total, over one million square meters of the exhibition area were leased. All this data means an increase compared to last years, and can be comparable with the year 2008, after which a decline was registered.

The article extends the current research of trade shows by analyzing exhibitors' motives for participating. The research is conducted for a traditional international agricultural fair called Bread Basket.

\section{Materials and methods}

The research focused on the studying of exhibitors' motives for exhibiting at the trade show. It aims to answer two basic research questions:

- What are the key reasons (factors) for exhibiting?

- How do selected variables affect these factors?

To answer the determined research questions, a factor analysis is conducted in order to identify key factors (reasons) of exhibitors exhibiting at the trade show. Subsequently, logistic regression 
makes it possible to reveal how selected variables affect these factors.

\section{Studied trade show - Bread Basket}

The Bread Basket trade fair is the oldest and most visited Czech agricultural fair organized since 1960. It takes place every year at the fair and exhibition center in České Budějovice. Last year (2014) the trade fair covered 36,121 square meters by 505 exhibitors' stands (18 of them being international). The Bread Basket event was visited by 98,652 visitors. According to the NACE classification, exhibitor categories included 11 crop production classes; 17 animal production classes and 152 agriculture technology types.

\section{Analysis of exhibitors' reasons}

The literature survey provided a list of possible reasons and motives for exhibiting at a trade show. This list is based on the following studies Bareczyk et al. (1998), Bello et al. (1990), and Kerin and Cron (1987), latterly adopted by Hansen (2004), Lee and Kim (2008) or Korneliussen (2011). Determined motives were tested in a pilot survey conducted among the agricultural companies attending Bread Basket in 2014. In this pilot survey, respondents had a possibility to add other motives for exhibiting at a trade show. The final list of motives was thus determined by the literature survey and pilot survey findings, demonstrated in an alphabetic order in the table 1 .

\begin{tabular}{|l|}
\hline Bring attention to the company existence \\
\hline Collect information about competitors \\
\hline Consolidate relations with media \\
\hline Introduce new products \\
\hline Keep the tradition of being here \\
\hline Maintain and develop contacts with current customers \\
\hline Maintain and improve the brand image \\
\hline Maintain and improve the company image \\
\hline Make contacts with new and potential customers \\
\hline Make contracts/deals \\
\hline Open up to new markets \\
\hline Provide information about product changes, improvements \\
\hline Search information about customers \\
\hline Search information about new technologies \\
\hline Search information about suppliers \\
\hline Social and informal contacts with business partners \\
\hline Test new products/services/technologies \\
\hline Train and develop the sales team \\
\hline
\end{tabular}

Source: own processing

Table 1: Table 1: A list of motives used for the survey.
The respondents were asked to evaluate a comprehensive list of 17 items on the 5-point scale ("strongly agree" to "strongly disagree"). A total of 103 companies were surveyed during the trade show time. According to Gardner in Small (2007), a minimum requirement for a factor analysis is typically the ratio of five cases to one variable, so this criterion was met. The reliability of data was subsequently tested by Cronbach's alpha, which was 0.799 . Cronbach's alpha was also used to identify internal consistency in the revealed factor, and consequently a factor analysis with VARIMAX rotation was applied as well. The Kaiser-Meyer-Olkin measure of sampling adequacy was higher than 0.6 , which is the required measure for a good factor analysis (Tabachnick, Fidell, 1996).

\section{Analysis of exhibitors" odds to exhibit at trade} show

The factors revealed in the factor analysis served for further analysis of exhibitors' motives to exhibit at trade show. After revealing the factors, exhibitors were surveyed again. The survey was conducted by e-mail communication and phone calls, based on the contacts gained at the trade show. The exhibitors were asked to identify which of the revealed factors is the most important for exhibiting at a trade show. Logistic regression was applied to reveal exhibitors' odds in relation to exhibitors' NACE classification, number of employees, year of establishment and frequency of exhibiting at trade shows. The general logistic regression function is determined as follows:

Model: $\ln$ (revealed factor) $=\alpha+\beta 1$ (NACE classification) $+\beta 2$ (number of employees) $+\beta 3$ (year of company establishment) $+\beta 1$ (regular attendance at trade show) $+\mathrm{e}$,

where $\alpha$ is constant, $\beta$ is coefficient of dependent variable, and e is error term.

The independent categorical variables were subsequently coded according to the studied variables. NACA classification of surveyed exhibitors was coded as: p-crop production; a-animal production; the reference category being agriculture technology. Number of employees and year of company establishment were continuous variables. Finally, regular attendance was coded as 1 - one to five years, 5 - five to ten years, the reference category being exhibitors exhibiting more than ten years. To test the developed model, Chi - square test, Cox\&Snell R Square and Nagelkerke R Square were applied. 


\section{Results and discussion}

The research shows that $78.9 \%$ of surveyed agricultural companies are present at the Bread Basket trade show on a yearly basis. Altogether $89.3 \%$ of these companies attended Bread Basket regularly during the last five years, and $69.2 \%$ of them even in the last ten years. The conducted survey building upon Likers scaling showed up that the most-agree motives for the trade show exhibiting are: making contacts with new and potential customers (mean value 1.24), maintaining and developing contacts with current customers (mean value 1.32), and finally searching information about customers (mean value 1.43). On the other hand, less important motives for exhibiting in the trade show is to train and develop the sales team (mean value 3.89), to bring attention to the company existence (2.99), and to consolidate relations with media (mean value 2.55), see table 2 .

\begin{tabular}{|l|c|c|}
\hline & Mean & S.D. \\
\hline Bring attention to the company existence & 2.99 & 0.78 \\
\hline Collect information about competitors & 1.46 & 0.73 \\
\hline Consolidate relations with media & 2.55 & 0.34 \\
\hline Introduce new products & 1.78 & 1.11 \\
\hline Keep the tradition of being here & 1.47 & 0.23 \\
\hline Maintain and develop contacts with current customers & 1.32 & 0.73 \\
\hline Maintain and improve the brand image & 1.85 & 0.69 \\
\hline Maintain and improve the company image & 1.85 & 0.56 \\
\hline Make contacts with new and potential customers & 1.24 & 0.45 \\
\hline Open up to new markets & 1.50 & 0.72 \\
\hline Provide information about product changes, improvements & 1.69 & 1.02 \\
\hline Search information about customers & 1.43 & 0.56 \\
\hline Search information about new technologies & 1.45 & 0.51 \\
\hline Search information about suppliers & 1.45 & 0.63 \\
\hline Social and informal contacts with business partners & 1.87 & 0.44 \\
\hline Test new products/services/technologies & 1.78 & 0.74 \\
\hline Train and develop the sales team & 3.89 & 1.16 \\
\hline
\end{tabular}

Source: own processing

Table 2: Evaluation of motives for exhibiting.

\section{Determination of key factors}

The factor analysis revealed seven primary factors. However, an analysis of the screen plot showed that 4 factors were actually more suitable (see table 3). In summary, they included the "searching information and company development" factor (factor 1), incorporating motives of searching information about customers, suppliers and company development in terms of extending activities with business partners and customers. Another factor (factor 2) can be named as "focus on company surroundings" in the terms of focus on media and competitors ${ }^{2}$. Factor 3 can be characterized as "product development" presenting information about new products, testing a new product, as well as searching information about new technologies to improve current products. "New market possibilities" form the last factor (factor 4), including the opening up to new markets with new products. Factor 3 has excellent internal consistency, factors 1 and 4 have good internal consistency, and only factor 2 has merely acceptable consistency.

\begin{tabular}{|l|l|l|l|l|}
\hline & Factor 1 & Factor 2 & Factor 3 & Factor 4 \\
\hline $\begin{array}{l}\text { Maintain and improve the } \\
\text { company image }\end{array}$ & 0.767 & & & \\
\hline $\begin{array}{l}\text { Maintain and develop contacts } \\
\text { with current customers }\end{array}$ & 0.738 & & & \\
\hline $\begin{array}{l}\text { Maintain and improve the brand } \\
\text { image }\end{array}$ & 0.781 & & & \\
\hline $\begin{array}{l}\text { Make contacts with new and } \\
\text { potential customers }\end{array}$ & 0.659 & & & \\
\hline $\begin{array}{l}\text { Search information about } \\
\text { customers }\end{array}$ & 0.830 & & & \\
\hline $\begin{array}{l}\text { Search information about } \\
\text { suppliers }\end{array}$ & 0.722 & & & \\
\hline $\begin{array}{l}\text { Social and informal contacts } \\
\text { with business partners }\end{array}$ & 0.742 & & 0.702 & \\
\hline $\begin{array}{l}\text { Collect information about } \\
\text { competitors }\end{array}$ & & 0.758 & & \\
\hline $\begin{array}{l}\text { Consolidate relations with } \\
\text { media }\end{array}$ & 0.845 & 0.623 & 0.902 & 0.897 \\
\hline Keep the tradition of being here & & 0.473 & & \\
\hline $\begin{array}{l}\text { Bring attention to the company } \\
\text { existence }\end{array}$ & & & 0.280 & \\
\hline $\begin{array}{l}\text { Provide information about } \\
\text { product changes, improvements }\end{array}$ & & & & \\
\hline $\begin{array}{l}\text { Search information about new } \\
\text { technologies }\end{array}$ & & & & \\
\hline $\begin{array}{l}\text { Test new products/services/ } \\
\text { technologies }\end{array}$ & & & & \\
\hline Train and develop the sales team & & & & \\
\hline Open up to new market & & & & \\
\hline Introduce new products & & & & \\
\hline Variance explained & & & \\
\hline Cronbach's alpha & & & & \\
\hline
\end{tabular}

Source: own processing

Table 3: Factor analysis results.

\section{Odds of exhibitors at the trade show}

A survey of agricultural exhibitors which was conducted subsequently and in which the exhibitors were asked to identify the most important factors ${ }^{3}$ for exhibiting at the trade show, revealed that

\footnotetext{
2 Factor 3 includes the motive of bringing attention to the company existence. This impact is not interpreted because it had a lower loading than 0.32, which is, according to Tabachnick and Fidell (1996), less than the required minimum for interpretation.

${ }^{3}$ The factors were described at a detailed level in order to provide respondents with a precise idea about motives included in the factors.
} 
the most important factor is searching information and company development (38.3\% respondents). The second most important factor is product development (31.0\% respondents), followed by focus on company surroundings $(21.4 \%$ respondents), and new market possibilities $(8.6 \%$ respondents).

Searching information and company development

Model 1: ln (searching information and company development $)=-1.353+0.857$ NACE classification (p) -0.435 NACE classification (a) -0.020 year of company establishment +1.035 attendance at trade show (1) +0.634 attendance at trade show (5).

The model analyzed reveals that companies oriented on crop production are 2.35 times more likely to exhibit at the trade show for searching information and company development than agriculture technology exhibitors. On the other hand, agriculture technology exhibitors are 2.77 times more likely to attend the trade show because of searching information and company development than animal production exhibitors. The length of the company existence has negative tendencies, but this predictor is not statistically significant in the developed model. The predictor of frequency of exhibiting at the trade show indicates that agriculture companies which exhibit at the Bread Basket not more than ten times are more likely to exhibit for searching information and company development than companies with more than a 10-year tradition (table 4 and table 5).

Focus on company surroundings

Factor 2: $\ln$ (focus on company surroundings) $=-1.420-0.573$ NACE classification $(p)$ - 0.294 NACE classification (a) - 0.002 year of company establishment +1.125 attendance at trade show $(1)+1.294$ attendance at trade show (5).

Logistic regression revealed that exhibitors in crop and animal production are less likely to exhibit for focusing on company surroundings than agriculture technology producers. Agriculture technology producers are 2.27 times more likely to do so than crop production exhibitors and 4.0 times more likely than animal production producers. The year of company establishment is statistically significant, however, the $\exp (\beta)$ coefficient is close to one, therefore no evident relation can be interpreted. Concerning the frequency of exhibiting at the trade show, only the parameter describing companies with five to ten years of history is statistically significant. Those exhibitors are 3.65 times more likely to exhibit for focusing on company surroundings than exhibitors with more than ten years of tradition (table 4 and table 5).

\section{Product development}

Factor 3: In (product development) $=-0.693$ +0.659 NACE classification $(p)+1.263$ NACE classification (a) +0.102 year of company establishment -0.327 attendance at trade show (1) +0.634 attendance at trade show (5).

The developed logit model showed that plant production exhibitors are 1.99 times more likely to exhibit at the trade show motivated by product development than agriculture technology exhibitors. Similarly, animal production exhibitors are 3.53 times more likely to exhibit at a trade show motivated by product development than agriculture technology exhibitors. The model revealed that exhibitors with five to ten years of tradition at the trade show are 1.88 more likely to exhibit than exhibitors with more than ten years of tradition (table 4 and table 5).

\section{New market possibilities}

Factor 4: In (new market possibilities) $=-1.154$ - 0.628 NACE classification (p) - 0.173 NACE classification (a) - 0.285 year of company establishment +1.634 attendance at trade show (1) +1.824 attendance at trade show (5)

An analysis of the factor called new market possibilities brings only one statistical parameter, which revealed that agriculture technology exhibitors are 6.25 times more likely to exhibit, being motivated by new market possibilities, than animal production exhibitors (see table 4 and table 5). 


\begin{tabular}{|l|c|c|c|c|}
\hline & Factor 1 & Factor 2 & Factor 3 & Factor 4 \\
\hline & $\operatorname{Exp}(\beta)$ & $\operatorname{Exp}(\beta)$ & $\operatorname{Exp}(\beta)$ & $\operatorname{Exp}(\beta)$ \\
\hline NACE classification (p) & $2.35^{* *}$ & $0.56^{* *}$ & $1.99^{* *}$ & 0.53 \\
\hline NACE classification (a) & $0.64^{*}$ & $0.75^{* *}$ & $3.53^{*}$ & $0.84^{*}$ \\
\hline Year of company establishment & 0.98 & $0.99^{*}$ & 1.11 & 0.75 \\
\hline Exhibiting at trade show (1) & $2.81^{*}$ & 3.08 & 0.72 & 5.12 \\
\hline Exhibiting at trade show (5) & $1.89^{*}$ & $3.65^{*}$ & $1.88^{*}$ & 6.19 \\
\hline
\end{tabular}

Note: Statistically significant at a level of $\alpha=5 \%$ **; $\alpha=10 \%$ *

Source: own processing

Table 4: Logit model $\exp (\beta)$ coefficients.

\begin{tabular}{|l|c|c|c|c|}
\hline & Factor 1 & Factor 2 & Factor 3 & Factor 4 \\
\hline Chi-square (sig.) & 0.003 & 0.001 & 0.004 & 0.006 \\
\hline 2 Log Likelihood & 336.656 & 564.076 & 213.413 & 506.101 \\
\hline Cox\&Snell Square & 0.031 & 0.062 & 0.038 & 0.092 \\
\hline Nagelkerke R Square & 0.062 & 0.100 & 0.102 & 0.131 \\
\hline $\begin{array}{l}\text { Hosmer and Lemeshow Test } \\
\text { (sig.) }\end{array}$ & 0.865 & 0.335 & 0.756 & 0.366 \\
\hline Percentage of right prediction & 86.6 & 65.4 & 92.1 & 67.9 \\
\hline
\end{tabular}

Note: Statistically significant at a level of $\alpha=5 \% * * ; \alpha=10 \% *$

Source: own processing

Table 5: Logit Models values.

\section{Conclusion}

The results presented in this paper come out from the studying of exhibitors' motives to participate and exhibit at the trade show. Exhibitors at the international agriculture fair "Bread Basket" were surveyed, including plant producers, animal producers and agriculture technology exhibitors. A list of potential motives to exhibit was offered to exhibitors and the analysis proved that the most important motives for exhibiting are making contacts with new and potential customers and maintaining and developing contacts with current customers. This is confirmed by the findings in Lilen's (1983) study and Kerin and Corn's (1987) study. The least important motives revealed for exhibiting were training and developing sales team, which cannot be supported by Barczyks'et al. (1989) and Shoham's (1992) findings.

The factor analysis revealed four main motives. These motives can be named as searching information and company development, focus on surroundings, product development and new market possibilities. The subsequent exhibitors' survey revealed that the most important factor was searching information and company development. These findings are in compliance with Smith (1998), or Přikrylová and Jahodová (2010). Also product development showed to be important for exhibitors, agreeing with Frain (1999).

Further analysis focused on explaining exhibitors' odds for exhibiting at the trade show according to the factors which were revealed in the factor analysis. Logistic regression revealed that plant production exhibitors are more likely to exhibit at the trade show motivated by searching information and company development and product development than agriculture technology exhibitors. On the other hand, they are less likely to exhibit due to a focus on company surroundings and new market possibilities, compared to agriculture technology exhibitors. In comparison to agriculture technology exhibitors, animal production exhibitors are more likely to exhibit at the events motivated by product development, and less likely to exhibit at the events motivated by searching information and company development, product development and new market possibilities. The parameter of the number of years of exhibitors' existence was not interpretable in the developed models. Finally, the parameter of tradition of the Bread Basket Fair attendance revealed that exhibitors with five to ten years of tradition are more likely to exhibit at the trade show motivated by all the analyzed factors than those exhibitors with more than a ten-year tradition. 
Literature survey proves that trade shows are important promotional tool, supported by Hansen (2004), Joeng and Arcilla (2014) or Situma (2012). Revealed motives in conducted research can help potential exhibitors in their decision-making process of exhibiting at a trade show. It makes also contribution to exhibitors in strategies formation in the terms of adding value to exhibitors.

\section{Acknowledgements}

The findings introduced in this paper arise from the research work facilitated by a grant providedby the Faculty of Economics and Management, Czech University of Life Sciences in Prague - no. 20131042.

\section{Corresponding author:}

Ing. Michaela Havliková, Ph.D.

Department of Economics, Faculty of Economics and Management, Czech University of Life Sciences Prague Kamýcká 129, Prague 6, 165 21, Czech Republic

Phone: +420 224382338,E-mail: havlikovam@pef.czu.cz

\section{References}

[1] AUMA. Successful Participation in Trade Fairs, 2011. [Online]. Available: http://www.auma.de/ _pages/e/12_Download/download/TradeFairPreparation/ Successful-Participation.pdf. [Accessed: 30 December 2014].

[2] Barbieri, C., Mahoney, E., Butler, L. Understanding the nature and extent of farm and ranch diversification in North America. Rural Sociology. 2008, Vol. 7, No. 2, p. 205-229. ISSN 15490813.

[3] Barczyk, C., George, B. G., Lesch, W. C. Trade Show Participation: Inter-Industry and Organizational Motives. Journal of Professional Services Marketing. 1989, Vol. 4, p. 131-147. ISSN 0748-4623.

[4] Bello, D. C. Industrial Buyer Behaviour at Trade Shows - Implications for Selling Effectiveness. Journal of Business Research. 1992, Vol. 25, p. 59- 80. ISSN 0148-2963.

[5] Bonoma, T. V. Get more out of your trade shows. Harvard Business Review. 1983, Vol. 61, No. 2, p. 75-83. ISSN 0017-8012.

[6] Cop, R., Kara, R. T. The role of trade fairs in industrial marketing: Defence industry trade fairs. Journal of Management, Marketing and Logistic. 2013, Vol. 1, No. 3, p. 156-172. ISSN 2148-6670.

[7] Frain, J. Introduction to marketing. $4^{\text {th }}$ ed. London: International Thomson Business, 1999, p. 320, ISBN 18-615-2147-2.

[8] Godar, S. H., O'Connor, P. J. Same time next year - Buyer trade show motives. Industrial Marketing Management. 2001, Vol. 30, No. 1, p. 77-86. ISSN 0019-8501.

[9] Hansen, K. Trade Show Performance: A Conceptual Framework and Its Implications for Future Research, 1996. [Online]. Available: http://citeseerx.ist.psu.edu/viewdoc/ download?doi=10.1.1.194.3128\&rep=rep1\&type=pdf. [Accessed: 4 June 2015].

[10] Hansen, K. Measuring performance at trade shows: scale development and validation. Journal of Business Research. 2004, Vol. 57, No 1, p. 1-13. ISSN 0148-2963.

[11] Jeong, L. S., Arcilla, R. Why Philippine Exporters Join the Manila FAME Trade Fairs? Paper presented as the DLSU Research Congress 2014. [Online]. Available: http:/www.dlsu.edu.ph/conferences/ dlsu_research_congress/2014/_pdf/proceedings/EBM-I-002-FT.pdf [Accessed: 1 December 2015].

[12] Kellezi J. The Effectiveness of trade Shows in Global Competition. European Academic Research, 2013, Vol. 1, No. 3., p. 265-274. ISSN 2286-4822.

[13] Kerin, R. A., Cron, W. L. Assessing Trade Show Functions and Performance: An Exploratory Study. Journal of Marketing. 1987, Vol. 51, p. 87-94. ISSN 0022-2429.

[14] Kirchgeorg, M., Springer, C., Kastner, E. Objectives for successfully participating in trade shows. Journal of Business \& Industrial Marketing. 2010, Vol. 25, No. 1, p. 63-72. ISSN 0885-8624. 
[15] Korneliussen, W. T. T. The dimensionality of trade show performance in an emerging market. International Journal of Emerging Markets, 2011, Vol. 6, No. 1, p. 38-49. ISSN 1746-8809.

[16] Lilien, G. L. A Descriptive Model of the Trade Show Budgeting Decision Process. Industrial Marketing Management, 1983, Vol. 12, No. 2, p. 5-29. ISSN 0019-8501.

[17] Lee, C. H., Kim, S. Y. Differentional effects of determinants of multi-dimensions of trade show performance by three stage of pre-show, at-show and post-show activities. Industrial Marketing Management. Vol. 2, No. 2, p. 133-153. ISSN 0019-8501.

[18] Přikrylová, J., Jahodová, H. Moderní marketingová komunikace (Modern marketing communication). $1^{\text {st }}$ ed. Prague: Grada. 2010, p. 303. ISBN 978-80-247-3622-8.

[19] Sanders, D. Trade Show, Fair or Exhibition? 2013 [Online]. Available: http://www.trade-show-pr. com/2013/02/22/trade-show-fair-or-exhibition-part-1/ [Accessed: 4 February 2015].

[20] Situma, S. P. The effectiveness of trade Shows and Exhibitions as Organizational marketing Tool. International Journal of Business and Social Science. 2012, Vol 3, No. 22, p 219-230. ISSN 2219-6021.

[21] Small, K., Social dimensions of community festivals: An application of factor analysis in the development of the social impact perception (SIP) scale. Event Management, 2007, Vol. 11, p. 45-55. ISSN 1525-9951.

[22] Shoham, A. Selecting and Evaluating Trade Shows. Industrial Marketing Management. 1992, Vol. 21, p. 335-341. ISSN 0019-8501.

[23] Sharland, A., Balogh, P. The Value of Nonselling Activities at International Trade Shows. Industrial Marketing Management. 1996, Vol. 25, p. 59-66. ISSN 0019-8501.

[24] Smith, T. M. The Effectiveness of Trade Show Efforts for Exhibitors of Woodworking Machinery. A Thesis in Forest Resources, The Pennsylvania State University, The Graduate School, School of Forest Resources, 1998. [Online]. Available http://isbm.smeal.psu.edu/isbm_smeal_psu_edu/ library/working-paper-articles/1998-working-papers/23-1998-the-effectiveness-of-trade-showefforts.pdf. [Accessed: 4 June 2015].

[25] Tabachnick, B., Fidell, L. Using multivariate statistics. New York: Harper Collins. 1996, p. 1024. ISBN 978-0205849574.

[26] Vysekalová, J. Veletrhy a výstavy: efektivní prezentace pro úspěšný prodej (Trade fairs and exhibitions: efficient presentation for successful sale), $1^{\text {st }}$ ed., Prague: Grada, 2004, p. 159. ISBN 80-247-0894-9.

[27] Yuksel, U., Voola, R. Travel trade shows: exploratory study of exhibitors' perceptions. Journal of Business and Industrial Marketing. 2014, Vol. 25, No. 4, p. 293-300. ISSN 0885-8624. 